Selcuk Journal of Agriculture and Food Sciences

http://sjafs.selcuk.edu.tr/sjafs/index

Research Article
SJAFS

(2019) 33 (3), 175-178

e-ISSN: $2458-8377$

DOI:10.15316/SJAFS.2019.171

\title{
Evaluation of Ovicidal Effect of Extracts from Hop, Oregano, Lemon Balm and Clove on the Sunn Pest, Eurygaster maura L. (Hemiptera: Scutelleridae)**
}

\author{
Fatma Nur ELMA ${ }^{1, *}$ \\ ${ }^{1}$ Selçuk University, Faculty of Agriculture, Department of Plant Protection, Konya, Turkey
}

\begin{tabular}{l}
\hline ARTICLE INFO \\
\hline Article history: \\
Received date: 19.04 .2019 \\
Accepted date: 29.07 .2019 \\
\hline Edited by: \\
Murat KARACA; Selçuk University, \\
Turkey \\
Reviewed by: \\
Kamuran KAYA; Hatay Mustafa Kemal \\
University, Turkey \\
Mahmut İSLAMOĞLU; Uşak Univer- \\
sity, Turkey \\
\hline Keywords: \\
Eurygaster maura \\
Humulus lupulus \\
Origanum vulgare \\
Syzygium aromaticum \\
Ovicidal effect
\end{tabular}

\section{Introduction}

The Sunn pest, E. maura is a very damaging insect pest of wheat and barley which are important crops in Turkey (Lodos, 1982). It has occurred a trouble in Middle Anatolia, particularly in Aksaray, Konya, Ankara and Kurşehir since 1995 (Şimşek et al, 1996). The Sunn pest feeds on ripenning wheat grains, damaged grains largely fall the quality of the cooking of the leaven. The stages of late nymphal development and the intensive feeding of newly emerged adults are important phases in the biological cycles for Eurygaster spp. In the early instars nymphs don't feed intensely. Feeding densities and the damage to crops increases rapidly after the third instar. The newly emerged adult insects begin to feed on wheat grains intensively (Paulian and Popov, 1980; Popov et al, 1996). The Sunn pest, during feeding with its piercing-sucking mouthparts, injects protein-degrading enzymes from salivary glands into the cereals to soften the food. As a result of feeding, the enzymes induce quick relaxation of dough,

\footnotetext{
* Corresponding author email: fdundar@selcuk.edu.tr

** Short communication
}

which concludes in the production of bread with a low volume and coarse texture (Boyd et al, 2002).

Many plants have been demonstrated to have insecticidal, ovicidal, anti-ovipositional effect, antifeeding and other features, which are helpful in pest management (Ertürk et al, 2006; Yanar and Düzdemir, 2012; Elma and Alaoğlu, 2014a; Taş et al, 2015). Plants consist of a plentiful source of bioactive chemicals (Kim et al, 2005). Monoterpenes, triterpenes and sesquiterpene lactones are samples of such metabolites that may have the commercial application (Heywood et al, 1977; Barney et al, 2005).

Turkey has an extraordinarily rich flora (Şimşek et al, 1996). In this study, the ovicidal effect of extracts of four plants, which exist in Turkish flora were determined under laboratory conditions against the sunn pest Eurygaster maura L. (Heteroptera: Scutellaridae).

\section{Materials and Methods}

\subsection{Insect rearing and egg production}

Eurygaster maura adults were collected from overwintering sites in Karadağ - Karaman Province, Turkey, and proceed with plucked fresh wheat plants in the laboratory at $26 \pm 1^{\circ} \mathrm{C}$ under long day photoperiod 
(16:8 $\mathrm{h}$ light and dark). After the eggs were laid by the adults, on the wheat leaves and white paper napkins, these eggs were collected daily and used in this study (Kivan, 2005).

\subsection{Plants and sample preparation}

The different parts (from leaves, flower buds or aerial parts) of lemon balm, hop, oregano and clove are used in this study (Table 1).

Table 1

List of the plant materials used against Eurygaster maura eggs.

\begin{tabular}{lcc}
\hline Family & Plant name & Tissue Used \\
\hline Lamiaceae & Lemon Balm & Leaves \\
Cannabaceae & Hop & Flower buds \\
Lamiaceae & Oregano & Aerial parts \\
Myrtaceae & Clove & Flower buds \\
\hline
\end{tabular}

They were dried at room temperature and were shredded to small size with a grinder (Retsch SM100). Five hundred grams of methanol (Merck \% 99.5) is added to 50 grams of dried plant and allowed to stand for six days in the dark. Then the plant suspension was sieved through Whatman No.1 filter paper before methanol was vaporized in a rotary evaporator (Heidolp-VAP Precision) at $35 \pm 2^{\circ} \mathrm{C}$. The resulting residue was dissolved in the pure water including $10 \%$ acetone (v/v) to yield doses containing $2.5 \%, 5 \%$, and $10 \%$ $(\mathrm{w} / \mathrm{w})$ plant extract. The control solution consisted of $10 \%$ acetone in distilled water $(\mathrm{v} / \mathrm{v})$.

\subsection{Ovicidal activity of plant extracts on eggs}

Table 2

Ovicidal effects of different concentrations of plant extracts against the eggs of $E$. maura (expressed by emergence inhibition index \% (EII))

\begin{tabular}{llcl}
\hline Materials & \multicolumn{3}{c}{ EII (Mean \pm SE) } \\
Concentrations (\%)
\end{tabular}

The results showed that the percent kill of egg masses of extracts were constantly increased by depending on the extract concentration. Similar results were reported by other studies in which different extracts had a dose-dependent effect on insect (Ouda et al, 1998; Phasomkusolsil and Soonwera, 2012; Zambare, 2012).

Secondary organic compounds contained in plants have a significant potential in pest management. It has been reported that these compounds exhibit toxins, ovicidal, repellent, oviposition deterrents and feeding deterrents on pests (Isman, 2006). There have been many studies on the ovicidal effect of the plant extracts to several species in different insect orders. (Javare-
The ovicidal activity of plant extracts was assessed against E.maura egg mass, aged one to three days old three egg masses (41-42 eggs) were dipped into different concentrations of plant extracts for three-five minutes. Eggs were then directly taken to a filter paper to soak in the surplus solution and dried for half an hour at the room temperature. After that, these eggs were placed in a petri dish. The eggs were incubated conditions at $26 \pm 1^{\circ} \mathrm{C}, 16 \mathrm{~h}$ light: $8 \mathrm{~h}$ dark for $7-8$ days. The numbers opened and unopened eggs were counted. The experiment was repeated three times. Each assay was consisted of three concentrations of plant extracts and one control. Unopened eggs were counted as dead. The ovicidal activity evaluating experiment data were calculated by emergence inhibition index (EII) (Ma, 2001) and calculated by the formula: $\mathrm{EII}=[(\mathrm{C}-\mathrm{T}) / \mathrm{C}]$ $100 \%$, Where $\mathrm{T}$ is emergence in the treatment and $\mathrm{C}$ is emergence in the untreated control (Mulla and Darwazeh, 1979).

\section{Results and Discussion}

The ovicidal effect on E. maura eggs of plant extracts, lemon Balm, hop, oregano and clove, is presented in table 2. Plant extracts showed variable toxicity to eggs of E. maura (ranged from 2.49 to $57.49 \%$ ). The inhibition of egg hatchability decreased significantly with plant extract concentration. Hop extract revealed the best result in inhibiting egg hatchability $(57.49 \%)$ at $10 \%$ concentration. Ovicidal effect for oregano and clove extracts was moderate and EII was 35\%, 32.5\% at $10 \%$ concentration, respectively. The inhibition of hatchability of the Lemon Balm extract was low and ranged from 2.49 to $15 \%$. gowda and Krishna Naik, 2007; Zambare et al, 2012; Yorulmaz Salman et al, 2014; Yorulmaz Salman et al, 2015; Alkan and Gökçe, 2017). But few studies reported on ovicidal effect of plant extracts against Sunn pest. Kivan (2005) reported that the toxic effect of azadirachtin (NeemAzal T/S) were investigated on egg, nymph and adult stages of the Sunn pest Eurygaster integriceps Put, and also reported that the mortality of eggs was recorded $36 \%$. In another study for ovicidal properties against E. maura reported that Foeniculum vulgare extract was found effective in causing $76.22 \%$ egg mortality among the methanol extracts of eight plants. (Elma and Alaoğlu, 2014b). 
Hops includes alpha acids, prenylflavanoids, beta acids and proanthocyanidins (Hoek et al, 2001; Taylor et al, 2003). The beta acid derivative of hop avoids plants from chewing and piercing-sucking insect pests (Hampton et al, 2002) and the two-spotted spider mite, Tetranychus urticae Koch (Jones et al, 1996; Jones et al, 2003). Future studies will need to be performed to detect whether the activity of Hop against egg of sunn pest is interceded by the acid compound. Moreover, recognition of the bioactive compounds of hop may enable to development of botanical insecticides.

\section{Conclusion}

In this study, ovicidal activity of some plant extracts against sunn pest, E. maura were investigated. Data showed that hop extract has potential to be used as part of an integrated pest management against sunn pest because they had the highest effect among the four plant extracts tested. In addition, these results could support the search for new natural products providing an alternative to synthetic ovicidal from other Turkish indigenous plants. However future studies are needed to study the chemical structure and action mechanism of the active principle. Moreover, it is necessary to investigate the extract's efficacy, usefulness and chemical stability in field conditions.

\section{References}

Alkan M, Gökçe A (2017). Toxicological and behavioral effects of some plant extract on Colorado potato beetle, Leptinotarsa decemlineata Say, 1824 (Coleoptera: Chrysomelidae). Türkiye Entomoloji dergisi 41 (3): 309-317.

Barney JN, Hay AG, Weston LA (2005). Isolation and characterization of allelopathic volatiles from mugwort (Artemisia vulgaris). Journal of Chemical Ecology 31 (2): 247-265.

Boyd DW JR, Cohen AC, Alverson DR (2002). Digestive enzymes and stylet morphology of Deraeocoris nebulosus (Hemiptera: Miridae), a predacious plant bug. Annals of the Entomological Society of America 95: 395-401.

Elma FN, Alaoglu Ö (2014a). Bazı bitki ekstraktlarının Avrupa Sünesi [Eurygaster maura L. (Heteroptera: Scutellaridae)]'nin farklı dönem nimflerine toksik etkileri. Türkiye entomoloji dergisi 38 (2): 181-188.

Elma FN, Alaoğlu Ö (2014b). Ovicidal and antiovipositional activities of some plant extracts on the Eurygaster maura L. (Heteroptera: Scutellaridae). International Journal of Ecosystems and Ecology Sciences (IJEES) 4 (1):67-72.

Ertürk Ö, Şekeroğlu V, Ünal HU, Arslan HG (2006). Lymantria dispar L. (Lepidoptera: Lymantridae)'ın larva gelişmesi üzerine bazı bitki özütlerinin antifeedant (iştah kesici) ve toksik etkileri. OMÜ Ziraat Fakültesi Dergisi 21(3): 289-295.
Hampton R, Nickerson G, Whitney P, Haunold A (2002). Comparative chemical attributes of native North American hop, Humulus lupulus var. lupuloides E. Small. Phytochemistry 61: 855-862.

Heywood VH, Harborne JR, Turner BL (1977). The biology and chemistry of the compositae. Academic Press, London.

Hoek AC, Hermans-Lokkerbol ACJ, Verpoorte R (2001). An improved NMR method for the quantification of $\alpha$-acids in hops and hop products. Phytochemical Analysis 12: 53-57.

Isman MB (2006). Botanical insecticides, deterrents, and repellents in modern agriculture and an increasingly regulated world. Annual Review of Entomology 51: 45-66.

Javaregowda, Krishna Naik L (2007). Ovicidal Properties of Plant Extracts Against the Eggs of Teak Defoliator, Hyblaea puera Cramer. Karnataka Journal of Agricultural Science 20 (2): 291-293.

Jones G, Campbell CAM, Pye BJ, Maniar SP, Mudd A (1996). Repellent and oviposition-deterring effects of hop beta-acids on the two spotted spider mite Tetranychus urticae. Journal of Pesticide Science 47: 165-169.

Jones G, Campbell CAM, Hardie J, Pickett JA, Pye BJ, Wadhams LJ (2003). Integrated management of two-spotted spider mite Tetranychus urticae on hops using hop beta-acids as an antifeedant together with the predatory mite Phytoseiulus persimilis. Biocontrol Sci ence and Technology 13: 241-252.

Kivan M (2005). Effects of Azadirachtin on the Sunn pest, Eurygaster integriceps Put. (Heteroptera, Scutellaridae) in the laboratory, Journal Central European Agriculture 6 (2): 157-160.

Kim HG, Jeon JH, Kim MK, Lee HS (2005). Pharmacological ectsofasaron aldehyde isolated from Acorusgram in eusrhizome. Food Science and Biotechnology 14 (5): 685-688.

Lodos N (1982). Türkiye Entomolojisi. Ege Üniversitesi Ziraat Fakültesi yayınları 429 (2): 406-424.

Ma DL (2001). Neem tree [Meliaceae: Azadirachta indica A. Juss.] extracts and their compatibility with other biorational options for the integrated management of Helicoverpa spp. [Lepidoptera:Noctuidae]. Brisbane: University of Queensland. p. 206.

Mulla MS, Darwazeh HA (1979). New insect growth regulators against flood and stagnant water mosquitoes-effects on nontarget organisms. Mosquito News 39: 746-755.

Ouda N, Al-Chalabi BM, Al-Charchafchi FMR, Mohsen ZH (1998). Insecticidal and ovicidal effects of the seed extract of Atriplex canescens against Culex quinquefasciatus. Pharmaceutical Bio$\operatorname{logy} 36(1): 69-71$. 
Paulian F, Popov C (1980). Sunn pest or cereal bug. Wheat Technical Monograph. Ciba-Geigy, Basel, Switzerland.

Phasomkusolsil S, Soonwera M (2012). The effects of herbal essential oils on the oviposition deterrent and ovicidal activities of Aedes aegypti (Linn.), Anopheles dirus (Peyton and Harrison) and Culex quinquefasciatus (Say). Tropical Biomedicine 29 (1): 138-150.

Popov C, Barbulescu A, Vonica I (1996). Population dynamics and management of Sunn pest in Romania. FAO Plant Production and Protection 138: 4759.

Şener B, Bingo F, Erdogan I, Bowers WS, Evans PH (1998). Biological activities of some Turkish medicinal Plants. Pure \&Applied Chemistry 70 (2): 403406.

Şimşek Z, Şimşek N, Özkan M, Derin A, Güllü M (1996). Türkiye'de Süne (Eurygaster spp.)'ye karş1 uygulanan kimyasal mücadelenin gelişimi ile Süne ve Kımıl (Aelia spp.)mücadelesinde izlenmesi gereken stratejiler. II. Ulusal Zirai Mücadele Ilaçlart Sempozyumu, 18-20 Kasım, Ankara, s. 101-113.

Taş MN, Uysal M, Çetin H (2015). Bazı bitki ekstraktlarının Callosobruchus maculatus (F.) (Col.: Bruchidae)'e olan kontak toksisiteleri. Bitki Koruma Bülteni 55 (3): 195-205.
Taylor AW, Borofsky E, Kennedy JA, Deinzer ML (2003). Hop (Humulus lupulus L.) proanthocyanidins characterized by mass spectrometry, acid catalysts, and gel permeation chromatography. Journal of Agricultural and Food Chemistry 51: 41014110.

Yanar D, Düzdemir O (2012). Bazı Bitki Ekstraktlar1nın ve Bitkisel Preparatların Fasulye Tohum Böceğine (Acanthoscelides obtectus (Say.)) Olan Etkisi. Tarım Bilimleri Araştırma Dergisi 6 (1): 36-40.

Yorulmaz SS, Sarıtaş S, Kara N, Ay R (2014). Acaricidal and Ovicidal Effects of Sage (Salvia officinalis L.) and Rosemary (Rosmarinus officinalis L.) (Lamiaceae) Extracts on Tetranychus urticae Koch (Acari: Tetranychidae). Journal of Agricultural Sciences 20 (4): 358-367.

Yorulmaz SS, Sarıtaş S, Kara N, Aydınlı F, Ay R, (2015). Contact, Repellency and Ovicidal Effects of Four Lamiaceae Plant Essential Oils against Tetranychus urticae Koch (Acari: Tetranychidae). TEOP 18 (4): 857 - 872.

Zambare SP, Kangade YP, Sharma CT, Mali K H (2012). Ovicidal effect of four plant extracts on the eggs of Corcyra cephalonica (Stainton). International Multidisciplinary Research Journal 2 (5):26-28. 